\title{
Effects of Endogen Erythropoietin on Parathormone Secretion
}

\section{Endojen Eritropoietinin Parathormon Salgısı Üzerine Etkileri}

\section{(D) Edip GÖNÜLLÜ1, (1) Sezai ÖZKAN², (1) Cihan ADANAŞ², (1) Mehmet Fatih ÖZBAY3, (1) Esat KILIÇ4, (1) Murat ATMACA 5}

'Bakırçay University Faculty of Medicine, Department of Anesthesiology and Reanimation, Clinic of Algology, İzmir, Turkey

${ }^{2}$ Van Yüzüncü Yıl University Faculty of Medicine, Department of Orthopedics and Traumatology, Van, Turkey

${ }^{3}$ Van Education and Research Hospital, Department of Internal Medicine, Van, Turkey

${ }^{4}$ Akdeniz University Faculty of Medicine, Department of Internal Medicine, Clinic of Oncology, Antalya, Turkey

${ }^{5}$ Medipol University Faculty of Medicine, Department of Endocrinology and Metabolism, İstanbul, Turkey

Cite as: Gönüllü E, Özkan S, Adanaş C, Özbay MF, Kılıç E, Atmaca M. Effects of Endogen Erythropoietin on Parathormone Secretion. Forbes J Med. 2021;2(3):171-174.

\section{ABSTRACT}

Objective: We hypothesize that tissue hypoxia would increase erythropoietin, as well as parathormone (PTH), secretion. To verify this hypothesis, patients who had undergone orthopedic surgery with a pneumatic tourniquet were evaluated for endogenous tissue hypoxia.

Methods: This study included 20 patients who underwent orthopedic surgery with a pneumatic tourniquet, wherein, 6 had diagnostic arthroscopy and 14 had anterior cruciate ligament reconstruction. All operations were performed under spinal anesthesia. The paired t-test was used to detect the differences between serial concentrations of parathyroid hormone, erythropoietin, calcium, and phosphorus levels before and after ischemia, where "p values" of $<0.05$ were considered significant.

Results: The average duration of ischemia that patients were exposed to during surgery was $57.40 \pm 22.65$ $\mathrm{min}$. After ischemia, parathyroid hormone and erythropoietin levels were significantly elevated $(\mathrm{p}<0.001$; $\mathrm{p}<0.001$ ). No significant difference was found in calcium and phosphorus levels in patients before and after ischemia. A positive correlation was found between parathyroid hormone and erythropoietin levels $(\mathrm{p}<0.05)$.

Conclusion: Our study is the first to show that the increase in erythropoietin levels in response to tissue hypoxia and increases the release of PTH.

Keywords: Erythropoietin, parathormone, hypoxia, pneumatic tourniquet

O̊z

Amaç: Hipotezimiz, doku hipoksisinin parathormon (PTH) kadar eritropoietin salgısını da artıracağıydı. Bu hipotezi doğrulamak için pnömatik turnike ile ortopedik cerrahi geçiren hastalar endojen doku hipoksisi açısından değerlendirildi.

Yöntem: Bu çalışmaya pnömatik turnike ile ortopedik cerrahi uygulanan 20 hasta dahil edildi. Altısına tanısal artroskopi, 14'üne ön çapraz bağ rekonstrüksiyonu yapıldı. Ameliyatların tamamı spinal anestezi altında yapıldı. Paratiroid hormonu, eritropoietin, kalsiyum ve fosfor düzeylerinin iskemi öncesi ve sonrasındaki seri konsantrasyonları arasındaki farkların saptanması için eşleştirilmiş t-testini kullandık, burada "p değerlerinin" <0,05 olması anlamlı kabul edildi.

Bulgular: Hastaların ameliyat sırasında maruz kaldıkları ortalama iskemi süresi $57,40 \pm 22,65$ dakika idi. İskemi sonrası paratiroid hormonu ve eritropoietin seviyeleri anlamlı olarak yükseldi ( $<<0,001 ; p<0,001$ ). İskemi öncesi ve sonrası hastalarda kalsiyum ve fosfor düzeylerinde anlamlı bir fark yoktu. Paratiroid hormonu ile eritropoietin düzeyleri arasında pozitif korelasyon vardı $(\mathrm{p}<0,05)$.

Sonuç: Çalışmamız doku hipoksisine yanıt olarak eritropoietin düzeylerindeki artışın PTH salınımını artırdığını gösteren ilk çalışma olması ile ayırt edilmektedir.

Anahtar Kelimeler: Eritropoietin, parathormon, hipoksi, pnömatik turnike
Received/Geliş: 30.09 .2021

Accepted/Kabul: 17.10.2021

Corresponding Author/ Sorumlu Yazar:

Sezai ÖZKAN MD

Van Yüzüncü Yıl University Faculty of Medicine, Department of Orthopedics and Traumatology,

Van, Turkey

Phone: +90 5054877170

doktorsezai@hotmail.com

ORCID: 0000-0003-4444-6939

${ }^{\circledR}$ Copyright 2021 by the İzmir Buca Seyfi Demirsoy Training and Research Hospital / Forbes Journal of Medicine published by Galenos Publishing House. Licensed by Creative Commons Attribution 4.0 International (CC BY)

${ }^{\circ}$ Telif Hakkı 2021 İzmir Buca Seyfi Demirsoy Eğitim ve Araştırma Hastanesi / Forbes Tıp Dergisi, Galenos Yayınevi tarafından yayınlanmıştır Bu dergide yayınlanan bütün makaleler Creative Commons 4.0 Uluslararası Lisansı (CC-BY) ile lisanslanmıştır. 


\section{INTRODUCTION}

Erythropoietin is a hormone that is primarily produced in the adult kidney and the liver of the fetus. The most important physiological function of erythropoietin is the maintenance of erythropoiesis in the bone marrow. ${ }^{1}$

However, erythropoietin receptors, of which the physiological significance are not very well understood, exist in many tissues, ${ }^{2,3}$ such as the parathyroid gland. ${ }^{4}$ Erythropoietin receptors are found in parathyroid cells; however, the effect of endogenous erythropoietin secretion on parathormone (PTH) secretion is unknown.

A recent study showed high levels of PTH in patients with anemia. ${ }^{5}$ Another study showed elevated levels of erythropoietin in cases of primary hyperparathyroidism. ${ }^{6}$ These data suggest that increased endogenous erythropoietin stimulates PTH secretion.

The most important stimulant of erythropoietin is hypoxia. ${ }^{7}$ We hypothesize that tissue hypoxia will increase erythropoietin, which will increase the PTH secretion. To test this hypothesis, patients undergoing orthopedic surgery with pneumatic tourniquet application were evaluated for endogenous tissue hypoxia. Pneumatic tourniquet application has long been used in orthopedic surgery due to its advantages in providing a bloodless area and reducing blood loss. ${ }^{8,9}$ However, it causes ischemic damage and hypoxia at the tissue level. ${ }^{10}$ This study aimed to investigate the effects of tissue hypoxia on erythropoietin and PTH secretion in patients undergoing surgery with pneumatic tourniquet application.

\section{METHODS}

This study was conducted at the Van Regional Training and Research Hospital Orthopedics Clinic between May 2014 and July 2014. A total of 20 patients who had pneumatic tourniquet application were included to evaluate the effect of tissue hypoxia on erythropoietin and PTH secretion. Of the 20 patients, 6 underwent diagnostic arthroscopy and 14 had anterior cruciate ligament reconstruction. All operations were performed under spinal anesthesia. Cases that required general anesthesia were excluded because of their potential effect on erythropoietin secretion. Similarly, patients with bone lesions were excluded because the manipulation could affect the calcium, phosphorus, and/or PTH secretion.

All data regarding the age and gender of patients and ischemia duration caused by pneumatic dilatation were recorded. Blood samples were taken after spinal anesthesia induction in all cases, both before and 20 min after pneumatic dilatation to determine calcium, phosphorus, PTH, and erythropoietin levels. Calcium and phosphorus levels were determined by a photometric method using the Modular 800 device, whereas PTH and erythropoietin levels were measured using a microparticulate chemiluminescence method with the Architect i2000SR device.

\section{Statistical Analysis}

Data from the study forms were recorded to a computer database, and statistical analysis was performed with Statistical Package for the Social Sciences 16 software. Laboratory results before and after ischemia were compared with the Student's t-test. The correlations were analyzed between variables using the Spearman correlation analysis. Results were presented as mean \pm standard deviation and a $\mathrm{p}$ value of $<0.05$ was regarded as statistically significant.

\section{RESULTS}

This study included 20 patients, of whom $70 \%$ were male and $30 \%$ were female. The mean age was $32.07 \pm 9.78$, and $30 \%$ and $70 \%$ of patients underwent arthroscopy and anterior cruciate ligament operations, respectively. The mean duration that patients were exposed to ischemia during surgery was $57.40 \pm 22.65 \mathrm{~min}$.

The pre- and post-ischemia laboratory findings of 20 patients in the study are shown in Table 1. A statistically significant increase was found in PTH and erythropoietin levels ( $p$ values for all parameters were $<0.001$ ). No statistically significant difference was found in pre- and post-ischemia calcium and phosphorous levels $(p=0.970, p=0.073)$.

A positive correlation was shown in the correlation analysis between age and pre-ischemia erythropoietin levels and

Table 1. The comparative analysis of pre- and post-ischemic parameters

\begin{tabular}{|l|l|l|l|l|}
\hline & N & $\begin{array}{l}\text { Pre-ischemia } \\
\text { Mean } \pm \text { SD }\end{array}$ & $\begin{array}{l}\text { Post-ischemia } \\
\text { Mean } \pm \text { SD }\end{array}$ & P value \\
\hline Erythropoietin $(\mathrm{mIU} / \mathrm{mL})$ & 20 & $7.16 \pm 3.26$ & $8.84 \pm 3.43$ & $<0.001$ \\
\hline Parathyroidhormone $(\mathrm{pg} / \mathrm{mL})$ & 20 & $38.73 \pm 20.16$ & $50.92 \pm 22.98$ & $<0.001$ \\
\hline Calcium $(\mathrm{mg} / \mathrm{dL})$ & 20 & $9.22 \pm 0.65$ & $9.21 \pm 0.59$ & 0.970 \\
\hline Phosphorus $(\mathrm{mg} / \mathrm{dL})$ & 20 & $3.77 \pm 0.55$ & $3.83 \pm 0.59$ & 0.073 \\
\hline SD: Standard deviation & & & \\
\hline
\end{tabular}


age, pre-ischemia, and post-ischemia PTH levels, and post-ischemia erythropoietin levels (all $\mathrm{p}<0.01$ ). A positive correlation was also found between preischemia PTH levels and age, pre- and post-ischemia erythropoietin levels, and post-ischemia PTH levels $(\mathrm{p}<0.05, \mathrm{p}<0.01, \mathrm{p}<0.01$, and $\mathrm{p}<0.01$, respectively). The calcium and phosphorous levels measured before pneumatic dilatation positively correlated with post-ischemia calcium and phosphorous levels (all $\mathrm{p}<0.01$ ). In addition, correlation analysis revealed that PTH increase due to ischemia correlated with erythropoietin increase $(\mathrm{p}<005)$. The Spearman correlation analyses of all parameters are shown in Table 2.

\section{DISCUSSION}

This study demonstrates that tissue hypoxia in patients operated on with pneumatic dilation increases erythropoietin and PTH levels. In addition, increased erythropoietin levels were correlated with increased PTH levels. The relationship between erythropoietin and PTH could not be fully explained. Anemia may develop early in the course of chronic kidney disease and is nearly universal in patients with stage 5 chronic kidney disease. The influence of PTH on erythropoiesis is mainly due to anemia and secondary hyperparathyroidism observed in patients with uremia. ${ }^{1112}$ Likewise, in vitro studies on mice demonstrated that high PTH concentrations could inhibit erythropoiesis..$^{13,14}$ Contrarily, in vitro studies, failed to prove the influence of PTH on human hematopoietic stem cells. .5.16 $^{-16}$

Myelofibrosis is thought to be a pathogenetic cause of anemia in primary and secondary hyperparathyroidism; however, data are controversial. Meytes et al. ${ }^{17}$ failed to show the existence of a proliferative effect of PTH on bone marrow fibroblasts in an in vitro study. Nevertheless, case presentations of primary hyperparathyroidism and myelofibrosis are reported, wherein myelofibrosis was resolved after parathyroidectomy. ${ }^{18.19}$ In light of these data, Bhadada et al. ${ }^{20}$ showed bone marrow fibrosis in half of the cases of primary hyperparathyroidism and anemia, and the anemia and myelofibrosis were resolved after parathyroidectomy.

Erythropoietin levels in primary hyperparathyroidism were also studied due to the relationship between elevated PTH levels and anemia. Kokot et al. ${ }^{6}$ showed elevated erythropoietin levels in patients

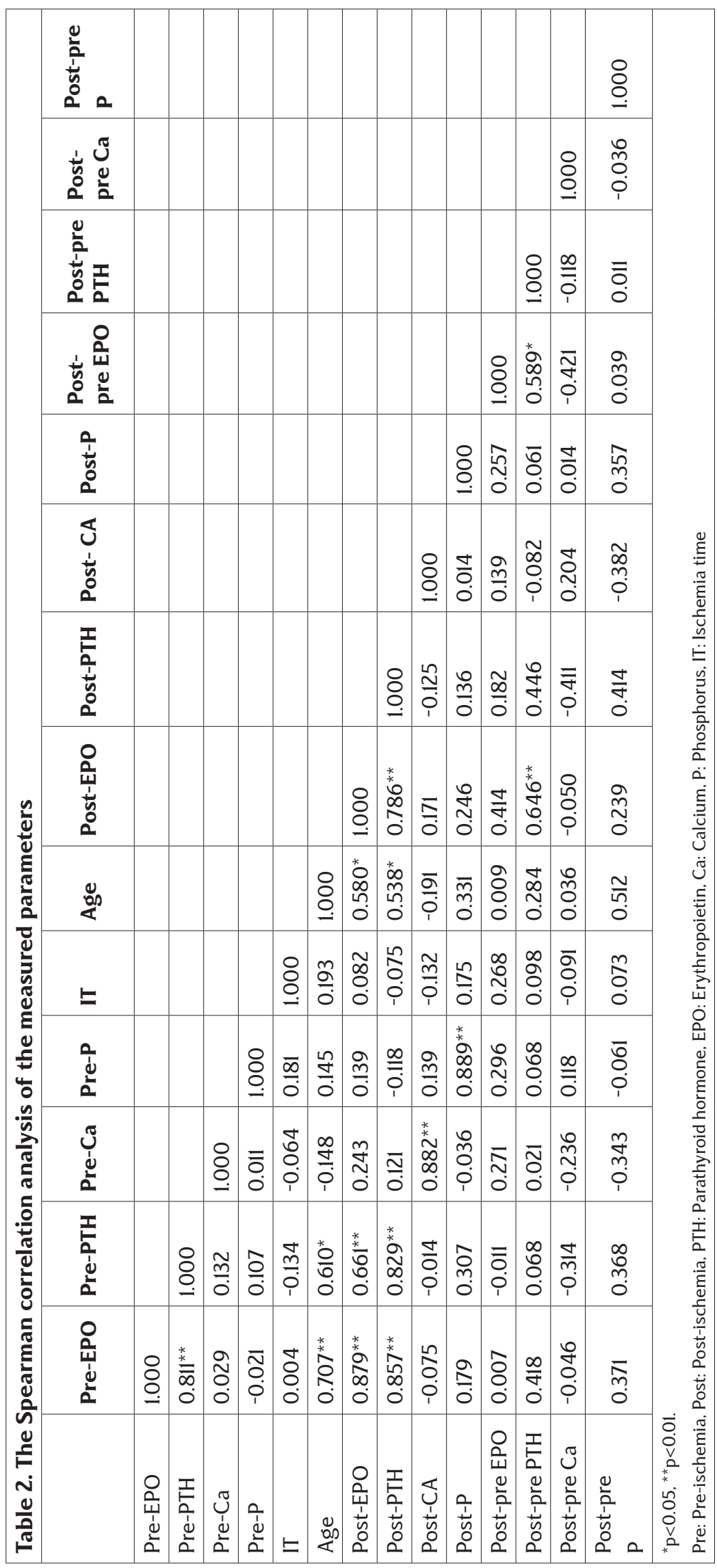


with primary hyperparathyroidism, which related it to renal dysfunction and anemia observed in patients with primary hyperparathyroidism. However, this study failed to completely evaluate the cause-effect relationship; erythropoietin elevation can also be a result of increased PTH. Thus in 2007, Oztürk et al. ${ }^{4}$ demonstrated the existence of erythropoietin receptors in parathyroidectomy specimens although the effect of these receptors on PTH secretion is unknown. Atmaca and Tasdemir ${ }^{5}$ revealed elevated levels of PTH in patients with deficiency anemia as a reflection of this. Our study detected increased levels of both erythropoietin and PTH after ischemia $(p<0.01)$. The unchanged calcium and phosphorus levels support the proposed influence of erythropoietin on PTH secretion.

\section{Study Limitations}

The small number of patients and the single-center study are our main limitations.

\section{CONCLUSION}

Our study is remarkable since, for the first time, it revealed that increased erythropoietin levels due to tissue hypoxia stimulate PTH secretion.

\section{Ethics}

Ethics Committee Approval: The study were approved by the Van Yüzüncü Yıl University of Local Ethics Committee (date/protocol no: 18.04.2014/06).

Informed Consent: Consent form was filled out by all participants.

Peer-review: Externally peer-reviewed.

\section{Authorship Contributions}

Surgical and Medical Practices: E.G., C.A., M.A., M.F.Ö., Concept: E.G., E.K., M.A., Design: E.G., S.Ö., C.A., Data Collection or Processing: C.A., E.K., M.F.Ö., Analysis or Interpretation: E.G., C.A., S.Ö., E.K., Literature Search: E.G., C.A., M.F.Ö., E.K., Writing: E.G., C.A., M.A.

Conflict of Interest: No conflict of interest was declared by the authors.

Financial Disclosure: The authors declared that this study received no financial support.

\section{REFERENCES}

1. Liboi E, Carroll M, D'Andrea AD, Mathey-Prevot B. Erythropoietin receptor signals both proliferation and erythroid-specific differentiation. Proc Natl Acad Sci U S A. 1993;90:11351-5.
2. Rózsás A, Berta J, Rojkó L, et al. Erythropoietin receptor expression is a potential prognostic factor in human lung adenocarcinoma. PLoS One. 2013;8:e77459.

3. Ogunshola OO, Bogdanova AY. Epo and non-hematopoietic cells: what do we know? Methods Mol Biol. 2013;982:13-41.

4. Oztürk M, Ustek D, Akbas F, et al. The presence of erythropoietin receptor in parathyroid cells. J Endocrinol Invest. 2007;30:RC35-7.

5. Atmaca M, Tasdemir E. Corelation of parathyroid hormone and hemoglobin levels in normal renal function. Acta Endocrinologica (Buc). 2011;7:317-23.

6. Kokot F, Nieszporek T, Wiecek A, Skrzypek J, Ziemiańczyk S, Jarzab B. Stezenie erytropoetyny $\mathrm{w}$ surowicy u chorych na pierwotna nadczynność przytarczyc [levels of erythropoietin in serum of patients with primary hyperparathyroidism]. Pol Arch Med Wewn. 1995;93:209-15.

7. Haase VH. Regulation of erythropoiesis by hypoxia-inducible factors. Blood Rev. 2013;27:41-53.

8. Cushing $\mathrm{H}$. Pneumatic tourniquets: with especial reference to their use in craniotomies. Med News. 1904;84:577-80.

9. Sharrock NE, Savarese JJ. Anesthesia for orthopedic surgery. In: Miller RD, ed. Anesthesia. 5th ed. New York: Churchill Livingston, 2000;2118-36.

10. Ostman B, Michaelsson K, Rahme H, Hillered L. Tourniquet-induced ischemia and reperfusion in human skeletal muscle. Clin Orthop Relat Res. 2004;(418):260-5.

11. Rao DS, Shih MS, Mohini R. Effect of serum parathyroid hormone and bone marrow fibrosis on the response to erythropoietin in uremia. N Engl J Med. 1993;328:171-5.

12. Cikrikcioglu MA, Karatoprak C, Cakirca M, et al. Association of calcium channel blocker use with lower hemoglobin levels in chronic kidney disease. Eur Rev Med Pharmacol Sci. 2013;17:2530-7.

13. Levi J, Bessler H, Hirsch I, Djaldetti M. Increased RNA and heme synthesis in mouse erythroid precursors by parathyroid hormone. Acta Haematol. 1979;61:125-9.

14. Meytes D, Bogin E, Ma A, Dukes PP, Massry SG. Effect of parathyroid hormone on erythropoiesis. J Clin Invest. 1981;67:1263-9.

15. Komatsuda A, Hirokawa M, Haseyama T, et al. Human parathyroid hormone does not influence human erythropoiesis in vitro. Nephrol Dial Transplant. 1998:13:2088-91.

16. Delwiche F, Garrity MJ, Powell JS, Robertson RP, Adamson JW. High levels of the circulating form of parathyroid hormone do not inhibit in vitro erythropoiesis. J Lab Clin Med. 1983;102:613-20.

17. Meytes D, Shacked N, Blum M, Ramot B. Effect of excess parathyroid hormone on human bone marrow fibroblasts. Nephron. 1990;55:6-9.

18. Lim DJ, Oh EJ, Park CW, et al. Pancytopenia and secondary myelofibrosis could be induced by primary hyperparathyroidism. Int J Lab Hematol. 2007;29:464-8.

19. Kumbasar B, Taylan I, Kazancioglu R, Agan M, Yenigun M, Sar F. Myelofibrosis secondary to hyperparathyroidism. Exp Clin Endocrinol Diabetes. 2004:112:127-30.

20. Bhadada SK, Bhansali A, Ahluwalia J, Chanukya GV, Behera A, Dutta P. Anaemia and marrow fibrosis in patients with primary hyperparathyroidism before and after curative parathyroidectomy. Clin Endocrinol (Oxf). 2009;70:527-32. 